\title{
Energy generation in a Microbial Fuel Cell using anaerobic sludge from a wastewater treatment plant
}

\author{
Vinicius Fabiano Passos, Sidney Aquino Neto, Adalgisa Rodrigues de Andrade, Valeria Reginatto*
}

\author{
University of São Paulo / FFCLRP - Dept. of Chemistry, Av. \\ dos Bandeirantes, 3900 - 14040-901 - Ribeirão Preto, \\ SP - Brazil. \\ *Corresponding author < valeriars@ffclrp.usp.br>
}

Edited by: Airton Kunz
Received May 08, 2015

Accepted September 13, 2015

\begin{abstract}
In microbial fuel cells (MFCs), the oxidation of organic compounds catalyzed by microorganisms (anode) generates electricity via electron transfer to an external circuit that acts as an electron acceptor (cathode). Microbial fuel cells differ in terms of the microorganisms employed and the nature of the oxidized organic compound. In this study, a consortium of anaerobic microorganisms helped to treat the secondary sludge obtained from a sewage treatment plant. The microorganisms were grown in a $250 \mathrm{~mL}$ bioreactor containing a carbon cloth. The reactor was fed with media containing acetate (as the carbon source) for 48 days. Concomitantly, the electrochemical data were measured with the aid of a digital multimeter and data acquisition system. At the beginning of the MFC operation, power density was low, probably due to slow microorganism growth and adhesion. The power density increased from the $15^{\text {th }}$ day of operation, reaching a value of $13.5 \mu \mathrm{W} \mathrm{cm}{ }^{-2}$ after ca. 24 days of operation, and remained stable until the end of the process. Compared with data in the literature, this power density value is promising; improvements in the MFC design and operation could increase this value even further. The system investigated herein employed excess sludge as a biocatalyst in an MFC. This opens up the possibility of using organic acids and/or carbohydrate-rich effluents to feed MFCs, and thereby provide simultaneous effluent treatment and energy generation. Keywords: microbial consortia, anode, power density, effluent
\end{abstract}

\section{Introduction}

Current energy production relies on fossil fuel consumption, which limits energy generation and dramatically contributes to climate change and environmental deterioration (Levin et al., 2004). Given this scenario, the development of technologies to obtain cleaner and renewable energy is highly desirable.

The use of biological systems for energy production has attracted the attention of researchers worldwide. With these systems, wastewater and organic residues with high concentration of pollutants can be applied as raw material to generate energy. These systems should offer a double benefit: potential remediation of effluents and concomitant output of renewable energy (Levin et al., 2004).

Microbial Fuel Cells (MFCs) are among the most prominent biological systems for energy production. The possibility of using microorganisms to generate electricity in fuel cells is based on the biochemical processes of energy production. Microorganisms degrade organic compounds by removing electrons from these compounds (oxidation) and releasing them to a final receptor, such as oxygen. However, even in the absence of oxygen, certain bacteria can transfer electrons from organic compound oxidation to systems outside the cell. These bacteria, known as exoelectrogenic bacteria, have found application as biological catalysts in MFCs. (Logan, 2009; Rachinski et al., 2010).

MFCs usually consist of two compartments separated by a membrane that prevents oxygen diffusion to the anode and enables the resulting protons to reach the cathode. An external circuit connects the two electrodes, allowing for electron transfer and use of the energy generated. In the anode compartment, a graphite cloth collects the electrons produced by the anaerobic microorganisms during substrate oxidation. In the aerobic cathode compartment, the electrons generated reduce oxygen and, together with protons, produce water (Logan, 2009).

The microorganisms used as biocatalysts in the anode can be pure or mixed cultures, like the anaerobic sludge from a biological wastewater treatment plant, which constitutes a good source of exoelectrogenic bacteria (Pham et al., 2006; Logan, 2009).

This study reports on the use of a consortium of microorganisms obtained from a biodigestor employed to treat excess sludge from an activated sludge wastewater treatment plant. The microorganisms were cultivated in a bioreactor (anode) and employed as biological catalysts in an MFC.

\section{Materials and Methods}

\section{MFC Inoculum}

The MFC inoculum was obtained from sludge collected from an anaerobic reactor. This sludge had been used to treat excess sludge originating from an activated sludge system employed to remediate the sewage of Ribeirão Preto, a city in the state of São Paulo, Brazil. Volatile solids concentration (VS) was determined according to Standard Methods (APHA, 2005); at the beginning, VS was $18.2 \mathrm{~g} \mathrm{~L}^{-1}$. 


\section{MFC construction and operation}

The MFC consisted of two identical chambers. The anode corresponded to a carbon cloth where microorganisms grew and formed biofilms. This chamber was fed with culture medium and was kept under anaerobic conditions by argon gas bubbling after each feed. A proton exchange membrane separated the chambers. The platinum cathode $\left(2 \mathrm{mg} \mathrm{cm}^{-2} \mathrm{Pt} 40 \mathrm{~m} . \mathrm{m}\right.$. \%), was positioned according to Figure 1 . The volume of each chamber (anode and cathode) was $250 \mathrm{~mL}$. Together, the electrodes (anode and cathode) comprised an area of $15 \mathrm{~cm}^{2}$.

At the beginning of the MFC operation, $150 \mathrm{~mL}$ of culture medium and $100 \mathrm{~mL}$ of anaerobic sludge were added to the anode. Every two days, for a period of 48 days, the anode compartment was fed with $100 \mathrm{~mL}$ of the culture medium containing sodium acetate $\left(10 \mathrm{~g} \mathrm{~L}^{-1}\right)$, as a carbon source, and it was enriched with micro- and macronutrients according to Lovley and Phillips (1988), as follows (concentrations given in $\mathrm{g} \mathrm{L}^{-1}$ ): $2.5 \mathrm{NaHCO}_{3 \prime}$ $0.1 \mathrm{CaCl}_{2} .2 \mathrm{H}_{2} \mathrm{O}, 0.1 \mathrm{KCl}, 1.5 \mathrm{NH}_{4} \mathrm{Cl}, 0.6 \mathrm{NaH}_{2} \mathrm{PO}_{4} . \mathrm{H}_{2} \mathrm{O}$, $1.87 \mathrm{Na}_{2} \mathrm{HPO}_{4} .12 \mathrm{H}_{2} \mathrm{O}, 0.1 \mathrm{NaCl}, 0.1 \mathrm{MgCl}_{2} .6 \mathrm{H}_{2} \mathrm{O}, 0.1$ $\mathrm{MgSO}_{4} \cdot 7 \mathrm{H}_{2} \mathrm{O}, 0.005 \mathrm{MnCl}_{2} \cdot 4 \mathrm{H}_{2} \mathrm{O}, 0.001 \mathrm{Na}_{2} \mathrm{MoO}_{4} \cdot 2 \mathrm{H}_{2} \mathrm{O}$, and 0.05 yeast extract.

The $\mathrm{pH}$ was adjusted to $7.0( \pm 0.2)$ with the aid of $\mathrm{NaOH} 5 \%(\mathrm{w} / \mathrm{v})$ or $\mathrm{HCl} 5 \%(\mathrm{v} / \mathrm{v})$, as monitored by a pHmeter. After each feed, argon gas was bubbled into the anodic compartment, to ensure anaerobiosis. During the experiment, the MFC system was magnetically stirred at $500 \mathrm{rpm}$. The temperature of the system was maintained at 27 and $33^{\circ} \mathrm{C}$.

In the cathode compartment, potassium permanganate $\left(\mathrm{KMnO}_{4}\right)$ at $0.2 \mathrm{~g} \mathrm{~L}^{-1}$ and $\mathrm{pH} 7.0( \pm 0.2)$ acted as the final electron acceptor. The anode and cathode were connected through an external resistor of $1000 \Omega$, by means of a copper wire.

Samples were periodically taken from the effluent withdrawn from the anode, filtered through $0.45 \mu \mathrm{m}$ cellulose acetate membranes, and frozen until total organic carbon (TOC) concentration had been measured by direct combustion-catalytic oxidation at $680^{\circ} \mathrm{C}$ using a Shimadzu TOC analyzer. TOC was detected by a nondispersive infrared gas analyzer (NDIR). To this end, 27 and $20 \mu \mathrm{L}$ of the sample were used for inorganic carbon (IC) and total carbon determination, respectively. Pre-

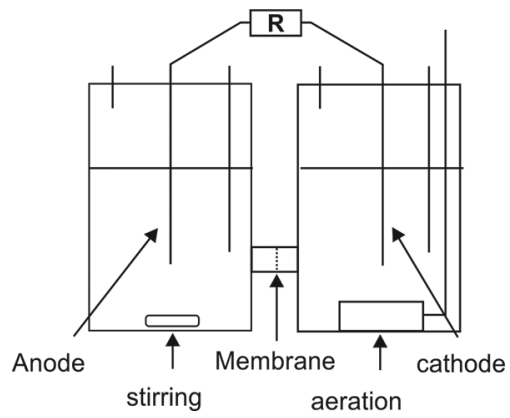

Figure 1 - A microbial fuel cell scheme, modified from Xiao et al. (2011). treatment for IC determination consisted of automatic addition of acid and gas (oxygen charger at $230 \mathrm{~mL}$ $\mathrm{min}^{-1}$ ) injection. The calibration condition corresponded to the standard self-dilution of potassium biphthalate at $1000 \mathrm{ppm}$, to give concentrations ranging from 50 to $1000 \mathrm{ppm}$. Data were acquired and processed by the TOC-Control V 1.07.00 software.

\section{Eletrochemistry assays}

The potential difference generated in the MFC was measured as a function of time with the aid of a digital multimeter. Data were collected and stored by a data acquisition system connected to a computer. On the basis of these data, power density $(\mathrm{P})$ was calculated by means of Equation 1:

$P=\frac{U^{2}}{A x R_{e x t}}$

where $U$ is the MFC potential (Volts), $A\left(\mathrm{~cm}^{2}\right)$ the geometric area of the anode, and $R_{\text {ext }}(\Omega)$ the external resistance.

The current (I) was calculated according to Ohm's law, expressed by Equation 2.

$I=\frac{U}{R_{\text {ext }}}$

Polarization curves were obtained by varying the external resistance ( $\Omega$ 56-1000) when the voltage had reached a stable maximum value in the MFC.

Coulombic efficiency (CE) was determined by calculating the loading (Q) of the MFC (Equation 3), the mass of $\mathrm{O}_{2}\left(\mathrm{mO}_{2}\right)$ (Equation 4), and the variation in chemical oxygen demand ( $\triangle \mathrm{COD}$ ) between the anode feeding periods (calculated from the TOC values by multiplying the average factor by 2.6 to transform TOC into COD).

$Q=i \times t$

where $i(\mathrm{~A})$ is the current of the MFC and $t(\mathrm{~s})$ the time elapsed between feedings of the anode; i.e., the same period considered for $\triangle \mathrm{COD}$ consumption (substrate).

$m \mathrm{O}_{2} \frac{Q \times M M}{n \times F}$

where $Q(\mathrm{C})$ is the load of the MFC, $M M\left(\mathrm{~g} \mathrm{~mol}^{-1}\right)$ the molar mass of $\mathrm{O}_{2}, n$ the number of $\mathrm{O}_{2}$ electrons, and $F$ (C) Faraday's constant.

These values helped determine coulombic efficiency $(C E)$ according to Equation 5.

$C E=\frac{m O_{2}}{\Delta \mathrm{DQO}} * 100$

\section{Results and Discussion}

About five days after the begining of the MFC operation, the current and power densities increased. Probably, this period was required by the microorganisms to adapt to the culture medium, to begin to adhere to 
the carbon cloth, and to produce the biofilm. The initial volatile solids concentration (VS) in the MFC was about $7.3 \mathrm{~g} \mathrm{~L}^{-1}$ (100 mL of inoculum containing $18.2 \mathrm{~g} \mathrm{~L}^{-1} \mathrm{VS}$ and $150 \mathrm{~mL}$ of culture medium). This value was higher but in the same order of magnitude as the $4 \mathrm{~g} \mathrm{~L}^{-1}$ reported by Oh and Logan (2005).

Figure 2 shows the current and power densities measured in the MFC over the 48 days of operation.

After approximately 25 days of operation, the current and power densities reached a plateau of around $430 \mu \mathrm{A} \mathrm{cm} \mathrm{cm}^{-2}$ and $13.5 \mu \mathrm{W} \mathrm{cm}{ }^{-2}$, respectively, and these values remained stable until the end of the MFC 48-day monitoring period.

Table 1 compares the MFC configurations, power densities, substrates, and sources of inoculum described in this work and reported in recent studies in the literature. The single-chambered MFC configuration employed by Logan et al., (2007) registered the highest power density values (Table 1). This configuration reduces the internal resistance of the system and facilitates electron

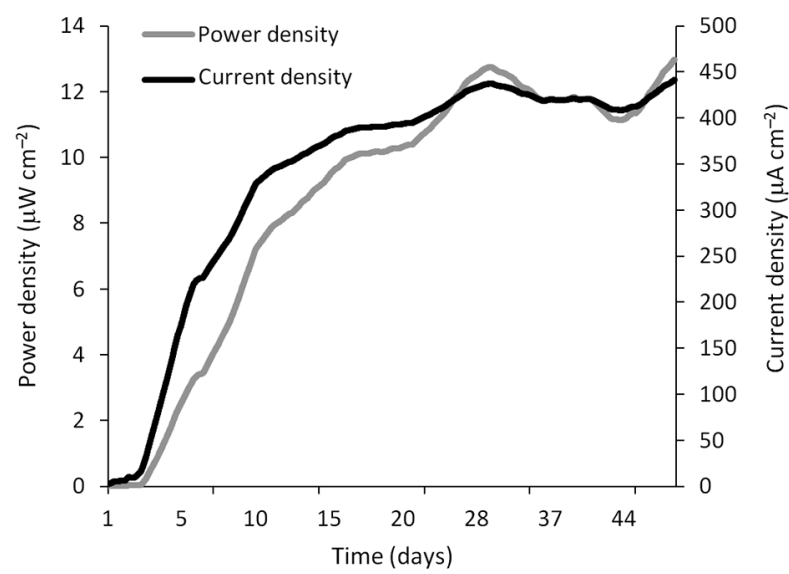

Figure 2 - Current and power densities during MFC (Microbial Fuel Cell) monitoring for 48 days; Rext $=1000 \Omega$. transfer between the anode and the cathode, thereby increasing the power in the system (Logan, 2006). In twocompartment MFCs, the proton-exchange membrane considerably increases the internal resistance to the flow of protons that is necessary to close the electrical circuit. According to Aquino Neto and Andrade (2013), Equation 8 gives the voltage generated in the MFC.

$\mathrm{U}_{\text {cell }}=\Delta_{E c \cdot E a}-\Delta \eta-\Sigma \Omega-\Delta £$

where the terms $E a$ and $E c$ represent the thermodynamic potential of the cathode and anode in volts. Analysis of this equation shows that overvoltage of the electrodes $(\Delta \eta)$ dissipates the total energy generated in the chemical cell by several orders of magnitude. This overvoltage comes from the low electron transfer rate at the cathode and anode, the ohmic drop $(\Sigma \Omega)$ associated with resistance of the diffusion system in the biofilm, membrane, and supporting electrolyte, and the natural tear resulting from system operating time $(\Delta £)$.

As regards the microorganism source (inoculum), it is possible to employ pure or mixed cultures as biocatalysts in the MFC anode. Microbial consortia (sludge) which oxidize organic compounds in the absence of oxygen consist of different groups of microorganisms (fermenting bacteria, acetogenic bacteria, and methanogenic archea). By means of sequential oxidation of organic compounds, these consortia withdraw electrons and transfer them to electron acceptors outside the cell. As a result, electrons generated in the oxidation reactions may be transferred from one microbial species to another, a phenomenon known as reducing equivalents interspecies transfer. If the anaerobic oxidation of organic matter is complete, acetate and/or $\mathrm{CO}_{2}$ serve as electron receptors, to produce $\mathrm{CO}_{2}$ and/or $\mathrm{CH}_{4}$ (Pham et al., 2006). Incomplete methanogenesis culminates in electron transfer to other receptors via suppression of the microorganisms which are responsible for this step in the mixed culture, a feature that is extremely desirable in an MFC catalyst

Table 1 - Comparison of MFC (Microbial Fuel Cell) performances in systems that employed different inoculum, substrate, and designs.

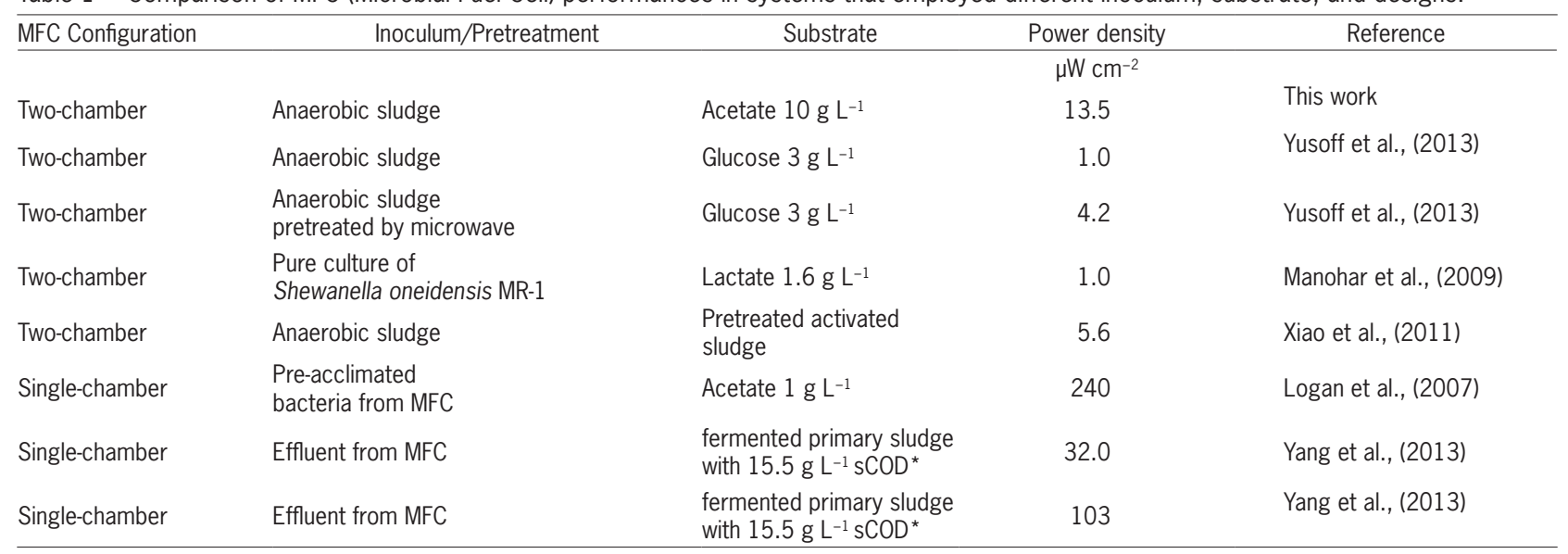

${ }^{*}$ Soluble COD (Chemical Oxygen Demand). 
(Logan, 2009). Therefore, some authors have pretreated the sludge by heating, microwave, or acidification, to suppress methanogenesis (Xiao et al., 2011). Table 1 lists a number of reports in the literature on MFCs that have used anaerobic sludge from wastewater treatment systems as the mixed culture. Mixed cultures are more resistant to system oscillations, and it is not necessary to work with them under sterile conditions.

Glucose (Catal et al., 2008) and organic acids and their salts (Logan et al., 2009; Manohar et al., 2009; Oh et al., 2005) are the preferred carbon sources for feeding MFC anodes. Some studies have demonstrated that it is possible to use industrial effluents with high COD in the anode (Liu et al., 2009; Wen et al., 2009; Wang et al., 2009). The use of acetate to feed the anode gives high power values, because bacteria easily oxidize this compound. By using acetate as a carbon source in a singlechambered MFC, Logan et al., (2007) achieved the highest power density. However, the inoculum used by these authors consisted of bacteria previously acclimated in another MFC.

Comparing the MFC data from published reports is not a trivial exercise, because the experimental setup varies (Table 1). Most of the studies that used systems similar to ours employed the same external resistor 1000 $\Omega$ ) (Yang et al., 2013; Xiao et al., 2011; Wang et al., 2013; Silva et al., 2013). The power density of $13.5 \mu \mathrm{W} \mathrm{cm} \mathrm{cm}^{-2}$ obtained herein is very promising as compared with recent results in the literature on MFC.

It was possible to construct polarization and power curves by varying the external resistance ( $\Omega$ 56-1000) after the voltage had reached a stable maximum value at day 40 (Figures $3 \mathrm{~A}$ and $\mathrm{B}$ ). The polarization curve helped to characterize the current as a function of the cell voltage. In the range of external resistors studied herein (between 56 and $1000 \Omega$ ), the maximum voltage (0.37 V) was found in the range of 370 to $1000 \Omega$. The total power generated from the cell depends on the electron flow, which is a function of the employed external resistance and the internally dissipated power in the MFC. Low external resistance affords high current but low useful power. The maximum useful power value is limited not by electrical factors but by the internal mass transport in the MFC.

The coulombic efficiency of the MFC investigated here, calculated for a resistance of $1000 \Omega$, was only 5 $\%$. Hence, $95 \%$ of the substrate was not employed to generate electricity. According to You et al., (2006), low electron recovery efficiency could be due to improper selection of exoeletrogenic bacteria from a microbial community as a result of an inadequate culture medium or environmental conditions. This selection could involve appropriate control of the nutrients during MFC operation. In general, low COD content enhances coulombic efficiency. The use of various types of sludge in MFCs like raw sludge (Xiao et al., 2011; Yusoff et al., 2013), primary sludge (Ge et al., 2013), and anaerobic sludge (Yang et al., 2013) have afforded coulombic effi-
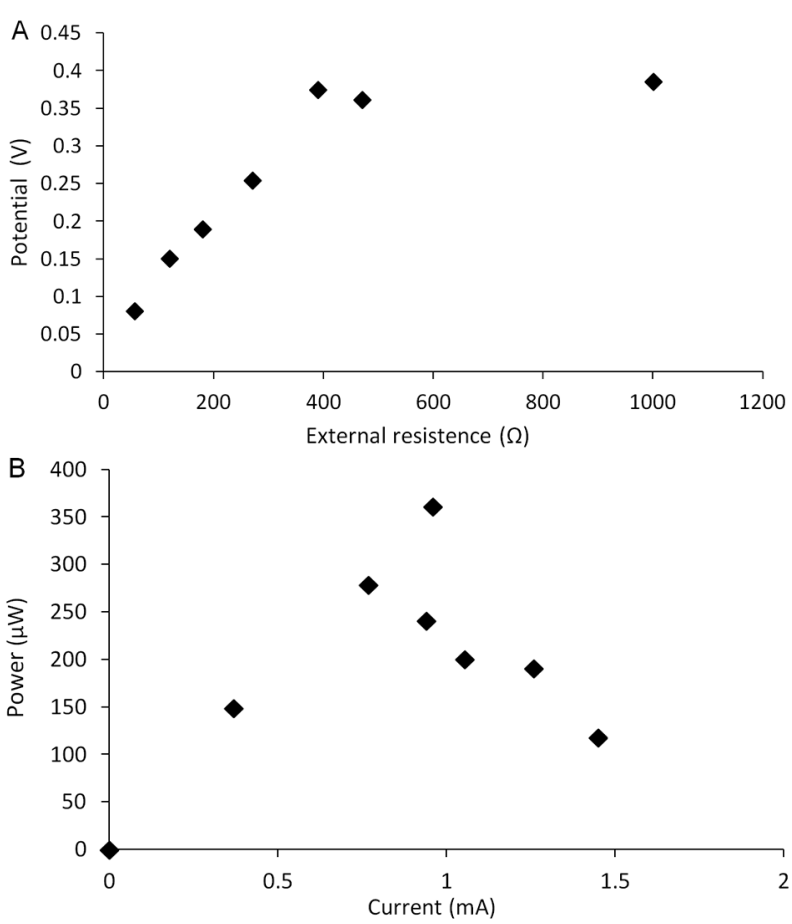

Figure 3 - Performance of the investigated MFC (Microbial Fuel Cell) upon varying external resistance $(A)$ and power as a function of the current (B).

ciency that resemble the coulombic efficiency achieved in the present study (3-7 \%). This low efficiency can be attributed not only to inadequate selection of noneletrogenic microorganisms, but also to reactor design (Abourached et al., 2014). For example, the energy efficiency obtained with a single-chamber MFC fed with acetate was 10-30\%, whereas a microbial fuel cell with double-cloth electrode assemblies (CEA-MFCs) achieved up to $70 \%$ coulombic efficiency (Fan et al., 2007; Liu et al., 2009).

\section{Conclusions}

The mixed culture from a biodigester used to treat excess sludge from an activated sludge system served as a good source of microorganisms for use as a biocatalyst at the anode of an MFC.

The power density obtained in this study -13.5 $\mu \mathrm{W} \mathrm{cm}^{-2}$-was in the same order of magnitude of other power densities reported in the literature. This value remained constant for a long operating period, which attested to the robustness of the system. Optimization of the MFC design, anode feeding, and cathode may increase this value even further.

To sum up, the system investigated herein employed excess sludge as a biocatalyst in an MFC. This opens the possibility of using organic acids- and/or carbohydrate-rich effluents to feed MFCs, and provide simultaneous effluent treatment and energy generation. 


\section{Acknowledgement}

The authors gratefully acknowledge the funding agencies $\mathrm{CNPq}$ (Brazilian National Council for Scientific and Technological Development) and FAPESP (São Paulo State Foundation for Research Support).

\section{References}

American Public Health Association [APHA]. 2005. Standard Methods for the Examination of Water and Wastewater. 19ed. APHA, Washington, DC, USA.

Abourached, C.; Lesnik, K.L.; Liu, H. 2014. Enhanced power generation and energy conversion of sewage sludge by CEAmicrobial fuel cells. Bioresource Technology 166: 229-234.

Aquino-Neto, S.; Andrade A.R. 2013. New energy sources: the enzymatic biofuel cell. Journal of The Brazilian Chemical Society 24: 1891-1912.

Catal, T.; Li, K.; Bermek, H.; Liu, H. 2008. Eletricity prodution from twelve monosaccharides using microbial fuel cells. Journal of Power Sources 175: 196-200.

Fan, Y.; Hu, H.; Liu, H. 2007. Enhanced Coulombic efficiency and power density of air-cathode microbial fuel cells with an improved cell configuration. Journal of Power Sources 171: 348-354.

Ge, Z.; Zhang, F.; Grimaud, J.; Hurst, J.; He, Z. 2013. Long-term investigation of microbial fuel cells treating primary sludge or digested sludge. Bioresource Technology 136: 509-514.

Levin, D.B.; Pitt, L.; Love, M. 2004. Biohydrogen production: prospects and limitations to practical application. International Journal of Hydrogen Energy 29: 173-185.

Liu, Z.; Liu, J.; Zhang, S.; Su, Z. 2009. Study of operational performance and electrical response on mediator-less microbial fuel cells fed with carbon- and protein-rich substrates. Biochemical Engineering Journal 45: 185-191.

Logan, B.E.; Hamelers, B.; Rozendal, S.; Schröder, U.; Keller, J.; Freguia, S.; Aelterman, P.; Verstraete, W.; Rabaey, K. 2006. Microbial fuel cells: methodology and technology. Environmental Science \& Technology 40: 5181-5192.

Logan, B.; Cheng, S.; Watson, V.; Estadt, G. 2007. Graphite fiber brush anodes for increased power production in air-cathode microbial fuel cells. Environmental Science \& Technology 41: 3341-3346

Logan, B.E. 2009. Exoelectrogenic bacteria that power microbial fuel cells. Nature Reviews Microbiology 7: 375-381.

\section{Abbreviations List}

$\Delta_{E c \cdot E a-}$ difference between the thermodynamic potential of cathode and anode

$\Delta \eta$ - overvoltage

$\Delta £$ - electrode wear out

$\Sigma \Omega$ - ohmic drop

$A$ - geometric area of the anode

$\mathrm{CE}$ - coulombic efficiency

COD - chemical oxygen demand

$F$ - Faraday's constant

I - current
Lovley, D.R.; Phillips, E.J.P. 1988. Novel mode of microbial energy metabolism: organic carbon oxidation coupled to dissimilatory reduction of iron or manganese. Applied and Environmental Microbiology 54: 1472-1480.

Manohar, A.K.; Mansfeld, F. 2009. The internal resistance of a microbial fuel cell and its dependence on cell design and operating conditions. Electrochimica Acta 54: 1664-1670.

Oh, S.; Logan, B.E. 2005. Hydrogen and electricity production from a food processing wastewater using fermentation and microbial fuel cell technologies. Water Research 39: 4673-4682.

Pham, T.H.; Rabaey, K.; Aelterman, P.; Clauwaert, P.; Schamphelaire, L.; De Boon, N.; Verstraete, W. 2006. Microbial fuel cells in relation to conventional anaerobic digestion technology. Engineering in Life Sciences 6: 285-292.

Rachinski, S.; Carubelli, A.; Mangoni, A.P.; Mangrich, A.S. 2010. Microbial fuel cells used in the production of electricity from organic waste: a perspective of future. Química Nova 33: 17731778 (in Portuguese, with abstract in English).

Wang, X.; Feng, Y.; Ren, N.; Wang, H.; Lee, H.; Li, N.; Zhao, Q. 2009. Accelerated start-up of two-chambered microbial fuel cells: effect of positive poised potential. Electrochimica Acta 54: 1109-1114.

Wang, Z.; Ma, J.; Xu, Y.; Yu, H.; Wu, Z. 2013. Power production from different types of sewage sludge using microbial fuel cells: a comparative study with energetic and microbiological perspectives. Journal of Power Sources 235: 280-288.

Wen, Q.; Wu, Y.; Cao, D.; Zhao, L.; Sun, Q. 2009. Electricity generation and modeling of microbial fuel cell from continuous beer brewery wastewater. Bioresource Technology 100: 41714175.

Xiao, B.; Yang, F.; Liu, J. 2011. Enhancing simultaneous electricity production and reduction of sewage sludge in two-chamber MFC by aerobic sludge digestion and sludge pretreatments. Journal of Hazardous Materials 189: 444-449.

Yang, F.; Ren, L.; Pu, Y.; Logan, B.E. 2013. Electricity generation from fermented primary sludge using single-chamber air-cathode microbial fuel cells. Bioresource Technology 128: 784-787.

You, S.J.; Zhao, Q.L.; Jiang, J.Q.; Zhang, J.N.; Zhao, S.Q. 2006. Sustainable approach for leachate treatment: electricity generation in microbial fuel cell. Journal of Environmental Science and Health Part A 41: 2721-2734.

Yusoff, M.Z.M.; Hu, A.; Feng, C.; Maeda, T.; Shirai, Y.; Hassan, M.A.; Yu, C.P. 2013. Influence of pretreated activated sludge for electricity generation in microbial fuel cell application. Bioresource Technology 145: 90-96.

IC - inorganic carbon

$\mathrm{mO}_{2}$ - mass of $\mathrm{O}_{2}$

MFC - Microbial Fuel Cell

MM - molar mass

$n$ - number of $\mathrm{O}_{2}$ electrons

$P$ - power density

$Q$ - loading

$t$ - time elapsed between feedings of the anode

$R_{\text {ext }}$ - external resistance.

TOC - Total Organic Carbon

VS - Volatile Solids

$U$ - potential 